\title{
Impact of Coronavirus (COVID-19) on the World Economy, 2020: A Conceptual Analysis
}

\author{
Nurul Mohammad Zayed ${ }^{1, *}$, Sunjida Khan ${ }^{2}$, Shahiduzzaman Khan Shahi ${ }^{1}$, Mithila Afrin ${ }^{3}$ \\ ${ }^{1}$ Department of Real Estate, Daffodil International University, Dhaka, Bangladesh. \\ ${ }^{2}$ Department of Business Administration, Daffodil International University, Dhaka, Bangladesh. \\ ${ }^{3}$ Department of English, East Delta University, Chattogram, Bangladesh.
}

\begin{abstract}
How to cite this paper: Nurul Mohammad Zayed, Sunjida Khan, Shahiduzzaman Khan Shahi, Mithila Afrin. (2021) Impact of Coronavirus (COVID-19) on the World Economy, 2020: A Conceptual Analysis. Journal of Humanities, Arts and Social Science, 5(1), 1-5.

DOI: $10.26855 /$ jhass.2021.01.001
\end{abstract}

Received: November 25, 2020

Accepted: December 28, 2020

Published: January 8, 2021

${ }^{*}$ Corresponding author: Nurul Mohammad Zayed, Department of Real Estate, Daffodil International University, Dhaka, Bangladesh.

Email: Zayed.bba@daffodilvarsity.edu.bd

\begin{abstract}
The outbreak of novel Coronavirus (COVID-19) has already disrupted the international economy in various ways and transformed into significant labor market shock. Both supply (production of goods and services) and demand (consumption and investment) are being affected by this pandemic. Both advanced and less advanced economies are seeking to cope with the pandemic, and all are facing limitations in their resource capacities; with the shortfall being more acute in the developing world. The purpose of this paper is to present some adverse impacts on global economy and to sketch out the economic scenario in different continents and forecast some suggestions to recover the situation of this crisis. The findings suggest that, the massive decline of world economy in 2020 could be recovered by the faster global and local recovery rates of economic activity in 2021 with the whole world awareness and cooperation.
\end{abstract}

\section{Keywords}

COVID-19, World Economy, Gross Domestic Product (GDP), Advanced Economies, Pandemic

\section{Introduction}

At present, the most popular and threatening term in the world is “COVID-19"-Corona Virus Disease 2019. It has a great disastrous impact on the entire world and creates severe level of uncertainty for the nations' people as well as the entire economy. Observing its hazardous effect, it is predicted that the main macroeconomic variables like GDP growth rate, employment, price level, capital will mostly be affected by this pandemic. Besides, an excessive obstacle has been appearing to achieve SDG's target for developing economy.

Initially, the disruptions of production appeared from Asia and have spread to supply chains over time across the world. Since there is a restriction on international travel and business industries are partly and fully closed, they incur severe challenges, such as sharp decline of revenue, decline of remittances, increase of unemployment, particularly those who are involved with air-travel, tourism, etc. Trade and manufacture industries, Small and Medium Enterprises (SMEs) etc., all sorts of production activities are disrupted and live with a threat and uncertain environment.

\section{Literature Review}

Clemens Breisinger et al. (2020) assumed that the COVID-19 hits all income groups of people particularly on less advanced and middle-advanced economies and the poor are affected mostly. Moreover, the restrictions of international travel and partial closure of trade and industries have led to a collapse in global travel and are feared to reduce 
the flows of remittances for Asia, Europe, and North America.

Furman (2020) stated the effect of COVID-19 is a new shock for economy which has never appeared earlier. Gopinath (2020) pointed out that the economic impact of this virus is increasing significantly in severe ways and already visible in many countries. China is the example of that kind of economy where from first two months in 2020 production and manufacturing sectors activities were sharply declined. Mauro et al. (2020) warned that the pandemic could have devastating effects on developing countries.

According to the UN Department of Economic and Social Affairs (DESA), the COVID-19 pandemic is disrupting global supply chains and international trade. "From an economic perspective, the key issue is not just the number of cases of COVID-19, but the level of disruption to economies from containment measures”, Ben May (2020), Head of Global macro research at Oxford Economics. Galí (2020) directed that the decline of economic growth rate, i.e., GDP is inevitable, and if the crisis prolonged for long time, the loss of output will be same or more than the financial crisis of 2007.

\section{Objectives}

The study seeks to find out the impact of COVID-19 on world economy. The following specific objectives of this paper are given below:

- To analyze the current and forthcoming impact of COVID-19 on international economy.

- To examine the economic scenarios of different continents.

- To state some suggestions for overcoming the obstacles arising in this crisis.

\section{Methodology}

The current study has been mainly focused on the effect of COVID-19 on global economy. Therefore, to achieve the aims, the paper is structured based on secondary data sources.

Secondary, data collected from various journals, publications and annual reports of world economics, WHO reports, authentic daily media news (television), current situation, annual reports of different economic analysis forums, daily newspapers, relevant articles, websites paper has carefully covered the present situation and performances of existing economic sectors to lead the analysis to more meaningful and logical conclusion. However, the secondary data sources have been carefully scanned prior to using them in this study.

\section{Analysis}

\subsection{Present and Upcoming Economic Impact:}

\subsubsection{Impact of COVID-19 on Economic Growth:}

COVID-19 crisis turned into pandemic from epidemic. The severe consequences of this crisis have been appearing on nation's population and world economy. The major macroeconomic indicators have been affecting most. The leading economic organizations in the world, such as: The IMF, UNIDESA, OPEC etc. projected that the world economy is going to experience the worst recession after the great depression in 2007. The continuous increase of lockdown would certainly cause the significant decline of the economic growth (GDP) of world's most forwarded economies (Figure 1).

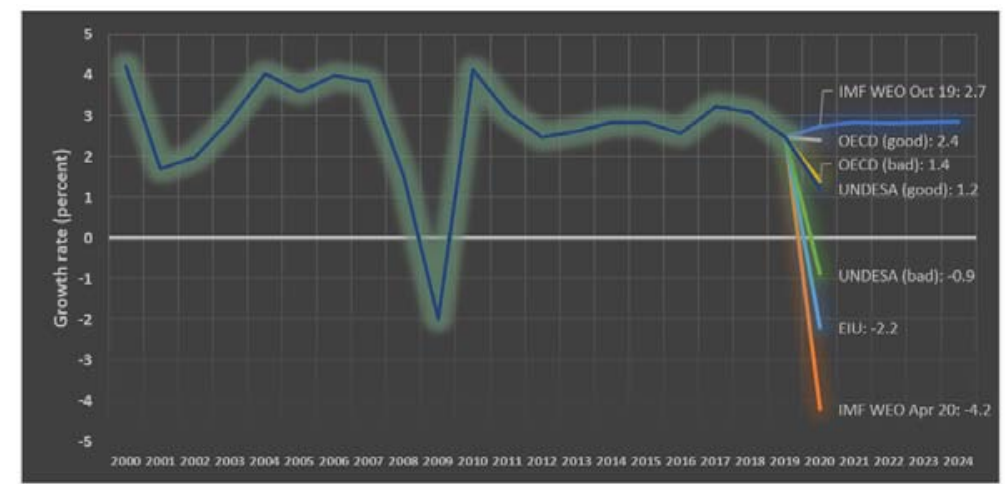

Figure 1. World Economic Growth outlook for 2020: latest projections by different organizations (Source: UNIDO elaboration on EIU, IMF, OECD and UNDESA). 


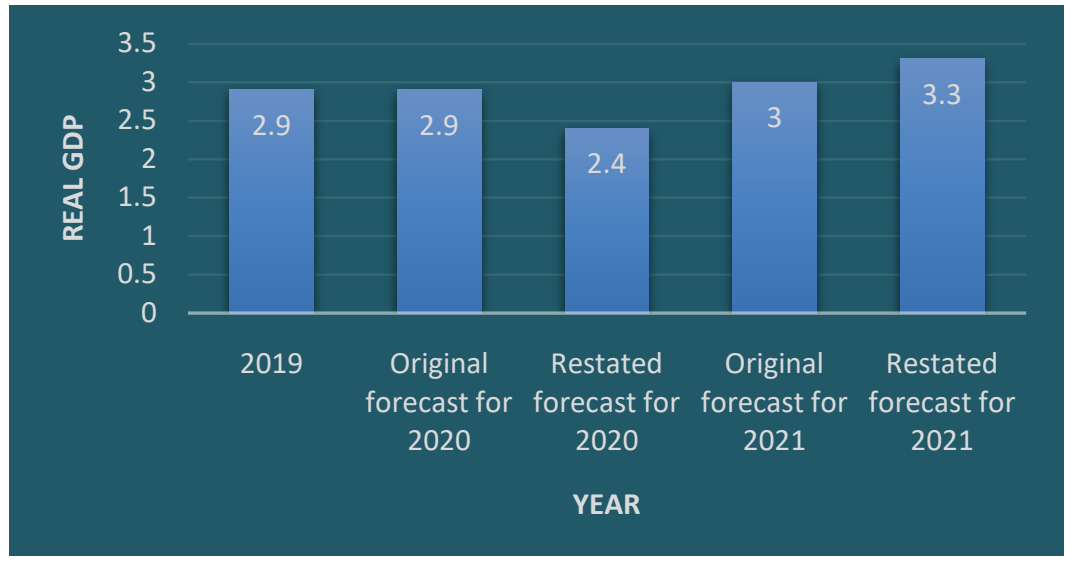

Figure 2. Forecasted global real GDP growth due to COVID-19 2019-2021 (Source: Statista 2020).

Due to severe impact of COVID-19, the global real GDP growth decreased by .05\% compared to its previous year. In 2019, the global real GDP estimated by 2.9\%, where in 2020 GDP growth predicted by 2.4\% (Figure 2).

\subsubsection{Impact of COVID-19 on Employment:}

The impact of the corona virus on employment as well as labor force is feared to be very terrible. Initially, ILO predicted that due to COVID-19, unemployment increased into 25 million, where losses of income range predicted from USD 860 billion to USD 3.4 trillion. But recently ILO's latest report states that approximate 2.7 billion workers are affected through this crisis that represents around $81 \%$ of the world's labor force (Figure 3).

\section{US jobless claims at record high}

Weekly total of unemployment claims in 2020

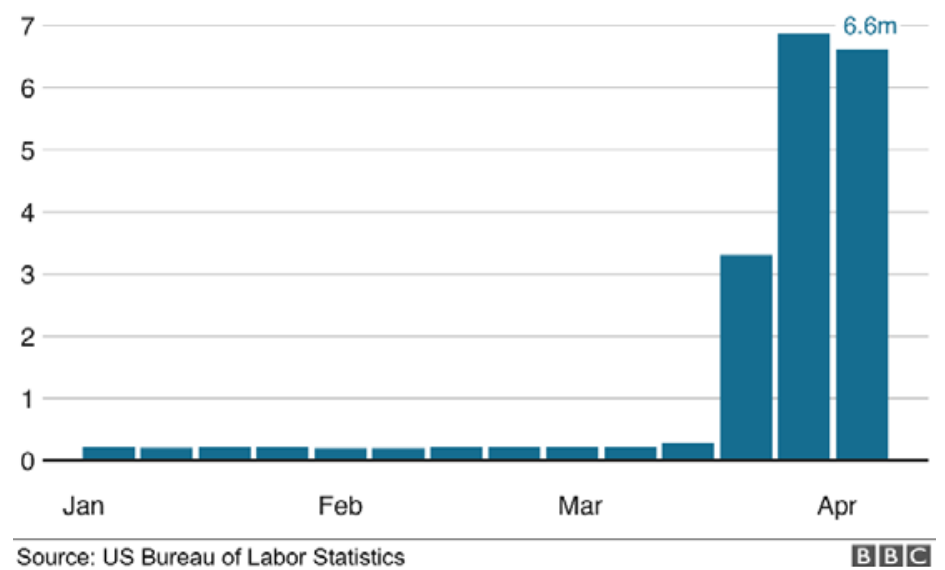

Figure 3. Unemployment of US.

In the United States, the number of unemployed people hits a high record, signaling an end to a decade of expansion for one of the world's largest economies.

The COVID-19 outbreaks on all income group of people particularly, the workforce of the middle and lower income countries will be affected rigorously. It is also doubted that migrant workers will lose their jobs immensely, as a consequence, economies with heavily depending on remittances will decline sharply. Moreover, developed economies have already started to decline their business and investment which will impact adversely on developing and less developing economies.

The COVID-19 hits all target for achieving Sustainable Development Goals (SDGs). It outbreaks all progress of alleviation of poverty as well as is increasing inequalities. The crisis will therefore inevitably and inversely affect the implementation of the 2030 Agenda for Sustainable Development. This pandemic is expected to adversely influence almost all SDGs. The current crisis will also severely affect the prospects for industrialization in developing countries. 
Trade and manufacture of developing nations are severely affected by this pandemic. Lower economies provide the raw materials and manufacturing items for advanced economies. The decrease of the demand of these products, decreases the production of the low income countries. Entire supply chains and value chains are being troubled. According to UN and IMF reports, a USD 50 billion decrease in manufacturing production in February 2020 and the negative economic effects will be felt "very intensively" in developing countries that provide raw materials. As consequences, the export volume of developing economies will decline and the losses of export revenue in 2020 are projected around USD 800 billion by UNCTAD.

\subsection{Impacts on Continents:}

\subsubsection{Impacts in Africa}

According to the African Union (AU) report, COVID-19 affects adversely on African economy. A sharp decrease in global oil price, lowering the production of manufacturer firms etc. hits severely on socio economic status in Africa. The following table indicates negative scenario of various economic sectors of Africa (Table 1).

Table 1. Declined Trade Percentage of Africa

\begin{tabular}{cc}
\hline Area & Percentage \\
\hline Automotive industry & $-44 \%$ \\
Airlines & -42 \\
Energy \& Basic materials industries & $-13 \%$ \\
MNE & $-16 \%$ \\
\hline
\end{tabular}

Source: African Union (AU) Report, 2020.

\subsubsection{Impacts in Latin America}

According to CEPAL (Economic Commission for Latin America and the Caribbean), the regional GDP of Latin America contracted by $1.8 \%$ and unemployment rate increased by $10 \%$ than previous year. A significant number of people living in poverty where this number estimated by 35 million to 220 million among the inhabitants of 620 million. Countries in Latin America like Chili, Peru, Brazil, Argentina, Uruguay etc. which have a good trade relation with China, faced most adverse impact of Corona.

\subsubsection{Impacts in Asia}

COVID-19 first appeared in China, Asia. China is one of the largest exporting nations in the world and it produces one-third of entire manufacturer goods in the world. China's industrial productions, trade, investment declined sharply from the first two months of the 2020. Therefore, economy moves on down that indicates less wealth and less employment. However, compared to other nations, India, the ASEAN-5 and NIEs have been less affected among Asia.

\section{Conclusion and Policy Recommendations}

The entire world should work together to ensure some basic phenomenon to combat any future pandemic like COVID-19. The government and policy makers should firstly emphasis on health protection and then ensure economic support for both supply and demand sides. We will need to develop better healthcare systems and sophisticated technologies to predict, detect and treat the patients in outbreak so that it does not turn into a pandemic at some point. Government resources should be spent and invested in a better way to fight the virus itself in the first place rather than treating patients after they get sick. We should inform people of every generation about how to behave and what to do during a pandemic and know what the term quarantine, self-isolation, flatten the curve means. We all should have a better understanding of how to do things during situations like this. We should be careful about staying clean and safe and follow state orders. Instead of being restless, we should be patient and wait until things get normal trying to make the use of the time, we have at home in order to make ourselves better rather than wasting these valuable resources. Bottom line, we should be prepared for this before the next time something like this happens because prevention is always better than cure.

$>$ Health protection from COVID-19 should be ensured for all labors and employers as well as their families.

$>$ A large range and synchronized policies should be formulated emphasis on such issues like employment 
generation, financial support and subsidy to stimulate the economy.

$>$ In both phases, it is important that the state assist the weaker links in the economy and society in a measured and focused manner.

$>$ Extended social protection based on Fiscal policy formulation.

$>$ Money policy should be formulated in such way where employment retention, short-time work, paid leave various subsidies etc. are emphasized.

$>$ Achieving higher economic output at the same time lowering the level of health risks via a policy that integrates the needs of the health system with those of the economic system.

$>$ Increase the scope of work: Enable better management of the economy while the pandemic is ongoing; allow more public sector workers to work remotely; support private sector companies as far as is possible to expand remote work capabilities; and add safeguards to enable employees to work safely in workplaces where remote work is not possible.

$>$ People should become more aware and obey the WHO rules and should stay home.

\section{References}

African Union Report-2020: https://au.int/en/reports.

Clemens Breisinger, A. A. (2020). Economic impact of COVID-19 on tourism and remittances: Insights from Egypt. IFPRI.

Furman, J. (2020). Protecting people now, helping. VoxEU eBook.

Galí, J. (2020). Helicopter money: The time is. VoxEU eBook.

Gopinath, G. (2020). Limiting the economic fallout. VoxEU eBook.

Mauro, R. B. (2020). Economics in the Time of COVID-19. VoxEU eBook.

Statista Trend Compass-2020: https://www.statista.com/statistics/1102691/china-estimated-coronavirus-covid-19-impact -on-gdp-growth/

United Nations Department of Economic and Social Affairs: https://www.un.org/development/desa/en/.

U.S Bureau of Labor Statistics: https://www.bls.gov/. 